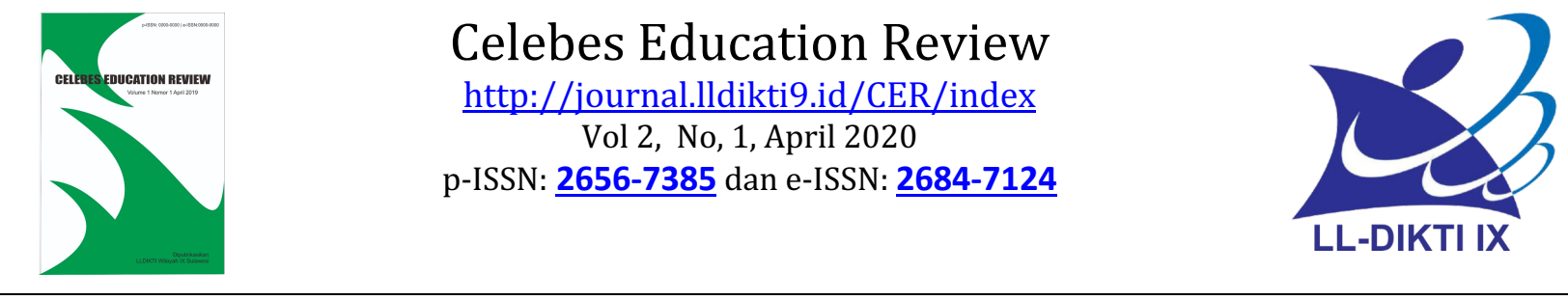

\title{
Implementasi Pendidikan Karakter Berbasis Masyarakat Pada Kegiatan Student Exchange Sd INP Tanetea Kecamatan Pajukukang Kabupaten Bantaeng
}

\author{
St. Wahidah 1 \\ 1 Pendidikan Bahasa Indonesia, Universitas Muhammadiyah Bulukumba \\ Email: st.wahidah191219@gmail.com
}

\section{Artikel info}

Artikel history:

Received; $12-03-2020$

Revised:24-03-2020

Accepted;28-03-2020
Keywords:

Pendidikan
Abstract. Many ways of character education in Indonesia. However, One method of character education is community-based student exchange can be implemented to students because in society there are religious, social and cultural values. Education and society are a unified whole that cannot stand alone. This research is a qualitative study using a phenomenological approach to uncover the implementation of community-based character education through the student exchange activities of SD INP Tanetea. The technique of Data collection were interviews, participatory observation, and documentation, while data analysis was performed using the Miles and Huberman models. Based on the results of the study, it can be concluded that the participation of the Pajukukang village community in student exchange activities can be said to be active and useful. But in an attitude of independence, it still does not look well. Supporting factors in this activity are family relationships and similarities in the while the inhibiting factor is the majority of biological parents visiting their children in the village. Therefore, commitment is needed between the teacher, student guardians, and the Pa'jukukang society to the agreed rules.

Abstrak. Terdapat banyak cara pendidikan karakter di Indonesia. Salah satu metode pendidikan karakter adalah student exchange berbasis masyarakat karena di dalam masyarakat terdapat nilai-nilai religius, sosial dan budaya. Pendidikan dan masyarakat merupakan satu kesatuan utuh yang tidak bisa berdiri sendiri. Penelitian ini penelitian kualitatif dengan menggunakan pendekatan fenomenologis untuk mengungkap implementasi pendidikan karakter berbasis masyarakat melalui kegiatan student exchange SD INP Tanetea. Teknik pengumpulan data ialah wawancara, observasi partisipatif, dan dokumentasi. Analisis data dilakukan dengan model Miles dan Huberman. Berdasarkan hasil analisis dapat disimpulkan bahwa partisipasi masyarakat desa Pajukukang dalam kegiatan student exchange dapat dikatakatan aktif dan baik. Namun dalam sikap kemandirian masih belum tampak dengan baik. Factor pendukung dalam kegiatan ini adalah hubungan kekeluargaan dan kesamaan dalam organisasi, sehingga mudah untuk koordinasi sedangkan faktor penghambat adalah mayoritas orang tua kandung menjenguk anak-anaknya di desa. Maka dari itu diperlukan komitmen antara guru, wali murid, dan masyarakat Pa'jukukang terhadap aturan-aturan yang sudah disepakati.

Coresponden author: Email: xxxx@gmail.com 


\section{PENDAHULUAN}

Sekolah sebagai sebuah lembaga pendidikan merupakan salah satu lembaga yang bertanggung jawab terhadap pembentukan karakter anak (character building). Oleh karena itu, peran dan kontribusi guru sangat dominan. Sebagai sebuah lembaga, sekolah memiliki tanggung jawab moral untuk mendidik anak agar pintar, cerdas, serta memiliki karakter positif sebagaimana diharapkan setiap orang tua. Namun sekarang ini, banyak orang mengeluh bahwa pendidikan karakter di sekolah telah diabaikan. Maka dari itu sekolah harus merespons kenyataan tersebut dengan membumikan gagasan pendidikan karakter melalui berbagai strategi untuk membentuk peserta didik yang berkarakter. Salah satu strategi tersebut adalah dengan menjalin kerjasama dengan masyarakat sekitar.

Hubungan sekolah dengan masyarakat merupakan bentuk hubungan komunikasi eksternal yang dilaksanakan atas dasar kesamaan tanggung jawab dan tujuan. Hubungan masyarakat dan sekolah adalah suatu proses komunikasi antara sekolah dengan masyarakat untuk meningkatkan pengertian masyarakat tentang kebutuhan, kegiatan pendidikan, serta mendorong minat dan kerjasama untuk masyarakat dalam peningkatan dan pengembangan sekolah. Hal ini sebagaimana dalam UU Sisdiknas no.20 tahun 2003 tentang peran serta masyarakat dalam pendidikan yang tertuang pada pasal 54 ayat (1) bahwa peran serta masyarakat dalam pendidikan meliputi peran serta perorangan, kelompok, keluarga, organisasi, profesi, pengusaha dan organisasi kemasyarakatan dalam menyelenggarakan dan pengendalian mutu pada satuan pendidikan. Kemudian dalam ayat (2) masyarakat dapat berperan serta sebagai sumber pelaksanaan dan pengguna hasil pendidikan. Maka peran serta masyarakat dalam pendidikan sangatlah diperlukan.

Masyarakat adalah sebuah miniature kecil dari sebuah negara. Dewasa ini hampir setiap kegiatan kehidupan masyarakat selalu dikaitkan dengan nilai-nilai pendidikan. Oleh karena itu, sulit dipisahkan antara pendidikan dengan kehidupan masyarakat. Pendidikan membutuhkan dukungan dari masyarakat, baik berupa penyediaan fasilitas, sistem sosial, budaya dan lain-lain, karena disini masyarakat diposisikan sebagai suatu subsistem yang ikut mensukseskan pelaksanaan proses pendidikan.

SD Inp Tanetea Kecamatan Pajukukang Kabupaten Bantaeng merupakan salah satu sekolah yang berada di wilayah Kecamatan Pajukukang Kabupaten Bantaeng yang termasuk dalam wilayah perkotaan. Menurut pengamat sosiologi dikatakan bahwa rasa saling mengenal dengan tetangga dalam masyarakat perkotaan telah tergerus disebabkan aktivitas mereka yang heterogen, ditambah lagi asal daerah tempat tinggal mereka. Hal ini tentunya akan berdampak pada sebagian besar peserta didik yang juga berasal dari lingkungan perkotaan. Atas dasar pemikiran itulah SD Inp Tanetea mengadakan kegiatan yang berbasis masyarakat.

Salah satu kegiatan SD INP Tanetea yang berbasis masyarakat adalah student exchange dengan lembaga pendidikan islam lain yang berada di suatu daerah dan masyarakat tertentu. Kegiatan student exchange SD INP Tanetea melibatkan beberapa masyarakat desa Pajukukang.

Istilah pendidikan berbasis masyarakat pada awalnya diperkenalkan oleh Comton and Mc Clusky dengan menggunakan istilah community education for development, yang diartikan sebagai sebuah proses dimana setiap anggota masyarakat hadir untuk mengemukakan setiap persoalan dan kebutuhan, mencari solusi di antara mereka, mengerahkan sumber daya yang tersedia dan melaksanakan suatu rencana kegiatan atau pembelajaran atau keduanya.

Pendidikan berbasis masyarakat (Community based education) adalah sebuah model pendidikan yang mengikutsertakan masyarakat di dalam penyelenggaraan dan pengelolaan pendidikan, maka pendidikan tersebut berakar dari masyarakat dan di dalam kebudayaan 
Pendidikan berbasis masyarakat merupakan pendidikan yang dirancang oleh masyarakat untuk membelajarkan masyarakat sehingga mereka berdaya, dalam arti memiliki kekuatan untuk membangun dirinya sendiri yang sudah barang tentu melalui interaksi dengan lingkungannya. Dengan demikian konsep pendidikan berbasis masyarakat mencakup: dari masyarakat, oleh masyarakat dan untuk masyarakat.

Pendidikan dari masyarakat artinya pendidikan merupakan jawaban terhadap apa yang menjadi kebutuhan masyarakat. Pendidikan oleh masyarakat artinya masyarakat merupakan pelaku atau subyek pendidikan yang aktif, bukan hanya sekadar obyek pendidikan. Pendidikan untuk masyarakat artinya masyarakat diikutsertakan dalam semua program yang dirancang untuk menjawab kebutuhan mereka.

Berdasarkan konsep di atas, dapat diketahui bahwa pendidikan karakter berbasis masyarakat adalah pendidikan yang dikelola oleh masyarakat, baik berbentuk formal maupun informal dengan memanfaatkan fasilitas yang ada menekankan pentingnya partisipasi masyarakat yang bertujuan untuk menanamkan nilai-nilai dan karakter yang baik, sehingga mampu menjawab kebutuhan masyarakat. masyarakat memiliki posisi yang urgen dalam keberlangsungan pelaksanaan pendidikan berbasis masyarakat, dan peran serta yang diambil oleh masyarakat tidak hanya sebagai donatur sekolah tetapi juga meliputi kebijakankebijakan yang akan diambil oleh sekolah tersebut dalam pelaksanaan pendidikan tersebut.

\section{METODE PENELITIAN}

Jenis dan Pendekatan Penelitian

Penelitian ini merupakan penelitian kualitatif dengan pendekatan fenomenologis. Penelitian ini membahas tentang implementasi pendidikan karakter berbasis masyarakat melalui kegiatan student exchange SD INP Tanetea di masyarakat desa Pajukukang, sehingga penelitian kualitatif sangat sesuai untuk mengungkap permasalahan tersebut.

Teknik Pengambilan Subjek

Teknik pengambilan subjek pada penelitian ini adalah menggunakan purposive sampling, yaitu teknik pengambilan sampel sumber data dengan pertimbangan tertentu. Informan dalam penelitian ini adalah kepala SD Inp Tanetea, kepala SD Inp Pajukukang, serta masyarakat desa Pajukukang yang berpartisipasi dalam kegiatan student exchange.

Teknik Pengumpulan Data

a. Wawancara

Wawancara dilakukan untuk menggali data-data terkait tentang implementasi pendidikan karakter berbasis masyarakat melalui kegiatan student exchange SD INP Tanetea di masyarakat desa Pajukukang kecamatan pajukukang Kabupaten Bantaeng,

b. Observasi Partisipatif

Observasi partisipatif dilakukan oleh peneliti yang juga bertugas sebagai guru pendamping dalam kegiatan student exchange tersebut.

c. Dokumentasi

Dokumentasi dalam penelitian ini digunakan untuk memperoleh data berupa catatan, buku panduan, dan foto-foto kegiatan student exchange.

\section{Teknik Analisis Data}

Analisis data dalam penelitian ini adalah menggunakan teori Milles dan Hubberman yang komponennya meliputi pengumpulan data, reduksi data (data reduction), sajian data (data display), dan penarikan kesimpulan dan verivikasi (conclusion drawing and verification).

\section{HASIL DAN PEMBAHASAN}

1. Partisipasi masyarakat dalam kegiatan student exchange 
Student exchange yang diadakan oleh SD Inp Tanetea Kecamatan Pajukukang tidak akan dapat berjalan dengan baik, manakala tidak ada kerjasama dengan SD Inp Pajukukang dan partisipasi masyarakat desa Pajukukang Kabupaten Bantaeng.

Masyarakat desa Pajukukang Kabupaten Bantaeng dipilih sebagai tempat pembelajaran anak-anak dikarenakan secara geografis masih berada di daerah pedesaan yang masih kental dengan nilai-nilai sosial. Selain itu kerjasama dengan sekolah dasar yang juga berbasis muhammadiyah menjadi pertimbangan utama, supaya dalam praktik pembelajarannya bisa saling membantu dan bertukar pengalaman. Bahkan mayoritas masyarakat Kranggan merupakan kader dari organisasi tersebut, sehingga mereka dengan suka rela menawarkan rumahnya sebagai tempat tinggal, makan, $\mathrm{MCK}$, dan lain sebagainya. Bahkan masyarakat mendidik murid-murid SD Muhammadiyah Paesan seperti mereka mendidik anak sendiri.

Hal ini menunjukkan bahwa masyarakat Desa Pajukukang mempunyai prinsip-prinsip pendidikan berbasis masyarakat sebagaimana menurut Michael W. Galbraith. Prinsipprinsip yang muncul dan tampak diantaranya adalah localization, integred delivery of service, accept diversity, Institusional responsive. Keterpaduan pemberi layanan pendidikan, serta mau menerima keberagaman latar belakang dan karakter anak merupakan prinsip yang paling tampak dari masyarakat Kranggan. Hal ini dikarenakan masyarakat ikut terlibat langsung dalam mendidik dan melayani anak-anak mulai dari aktivitas pagi hari sampai malam hari. Maka berdasarkan hal tersebut, dapat dikatakan bahwa masyarakat desa Kranggan Tersono Batang sangat berperan aktif dan baik dalam membantu kegiatan student exchange.

2. Nilai-nilai karakter yang muncul dalam kegiatan student exchange

Nilai-nilai karakter yang dibidik oleh SD Inp Tanetea melalui kegiatan student exchange adalah sikap sholeh, kreatif, dan mandiri sesuai dengan visi sekolah. Dari ketiga karakter inilah, ternyata sikap sholeh dan kreatif anak-anak yang paling berkembang, seperti mayoritas anak-anak melalukan sholat lima waktu berjamaah di masjid desa tersebut, mengikuti TPQ, pengajian subuh, sholat tahajud bersama "keluarga baru" mereka di desa, dan bermain dan belajar dengan alat-alat tradisional yang berada di lingkungan desa. Sedangkan pada sikap kemandirian masih belum tampak dengan baik, dikarenakan mayoritas anak-anak masih minta untuk dijenguk ayah ibu kandungnya, bahkan ada yang menangis sendiri ketika ingat dan bertemu dengan orang tuanya. Meskipun ada dua anak yang tidak dijenguk sama sekali.

Berdasarkan hasil penelitian dapat diketahui bahwa nilai karakter yang berkembang selain sholeh dan kreatif adalah sikap bersahabat dan peduli sosial maupun lingkungan. Tentunya nilai tersebut juga akan bermanfaat ketika anak sudah besar nanti, mereka dapat bergaul dengan siapa saja dan mempunyai rasa simpati dan empati yang tinggi kepada masyarakat yang kekurangan ekonomi.

Dalam implementasi pendidikan berbasis masyarakat melalui kegiatan student exchange, terdapat hal-hal yang menjadi faktor pendukung kegiatan tersebut, diantaranya adalah

a. Tokoh masyarakat desa Pajukukang yang aktif mengkoordinir warga dalam pelaksanaan student exchange. Hal ini dikarenakan tokoh tersebut masih mempunyai hubungan keluarga dengan salah satu pengurus SD Inp Tanetea.

b. SD Inp Pajukukang dan masyarakatnya berada dalam naungan organisasi yang sama dengan SD Inp Taneteai, sehingga dalam koordiansi dan kerjasama terasa lebih mudah.

Akan tetapi dalam implementasi pendidikan berbasis masyarakat, juga terdapat halhal yang menjadi faktor penghambat, diantaranya adalah

a. Mayoritas orang tua kandung menjenguk anak-anaknya di desa tersebut sambil membawakan makanan, bahkan ada yang membawakan baju kotornya untuk dibawa pulang. Padahal dengan adanya kegiatan seperti ini, anak dibiasakan untuk mencuci bajunya sendiri, dan makan apa adanya guna melatih kemandirian anak. 
b. Sebagian masyarakat desa Pajukukang juga kadang merasa malu jika tidak melayani anak dengan baik. Sehingga mereka memasakkan makanan yang lebih enak dari biasanya, serta memberikan jajan. Bahkan ada juga yang terkesan membiarkan dan tidak peduli dengan pendidikan karakter anak, yang terpenting bagi mereka adalah anak supaya betah dan dapat bermain dengan temannya di desa.

Berdasarkan hal tersebut, maka kriteria terpenting dalam efektivitas implementasi pendidikan karakter berbasis masyarakat adalah komitmen antara guru, wali murid, dan masyarakat Pajukukang terhadap aturan-aturan yang sudah disepakati dalam kegiatan student exchange. Serta kewajiban pihak sekolah untuk mengoptimalkan monitoring terhadap anak-anak di desa, sehingga program sekolah yang sudah disusun, dapat dilaksanakan dengan efektif dan efisien.

\section{PENUTUP}

Berdasarkan pembahasan diatas, maka dalam penelitian ini dapat disimpulkan beberapa temuan penting, diantaranya adalah: Pertama, masyarakat desa Pajukukang Kecamatan Pajukukang Kabupaten Bantaeng berpartipasi dengan aktif dan baik dalam kegiatan ini. Prinsipprinsip yang muncul dan tampak diantaranya adalah localization, integred delivery of service, accept diversity, Institusional responsive, Kedua, Nilai-nilai karakter yang berkembang selain sholeh dan kreatif adalah sikap bersahabat dan peduli sosial maupun lingkungan. Namun dalam sikap kemandirian masih belum tampak dengan baik, dikarenakan mayoritas anak-anak masih minta untuk dijenguk ayah ibu kandungnya. Ketiga, faktor pendukung dalam kegiatan ini adalah hubungan kekeluargaan dan kesamaan dalam organisasi, sehingga mudah untuk koordinasi. Sedangkan faktor penghambat adalah mayoritas orang tua kandung menjenguk anak-anaknya di desa, dan masyarakan desa Pajukukang juga kadang merasa malu jika tidak melayani anak dengan baik. Maka dari itu diperlukan komitmen antara guru, wali murid, dan masyarakat Kranggan terhadap aturan-aturan yang sudah disepakati.

\section{Refference}

Bagong, Suyanto, "Pendidikan Berbasis Masyarakat:Prasyarat yang Dibutuhkan”, (Jurnal Edukasi, Vol I, No 1, 2005).

Haris, A.S. "Pengembangan Sekolah Melalui Partisipasi Masyarakat: Sebuah Kajian Operasional Tingkat Sekolah", (Seminar Program Pasca Sarjana Universitas Negeri Yogyakarta, 19 Mei 2001.

Kesuma, Dharma, dkk, "Pendidikan Karakter, Kajian Teori dan Praktik di Sekolah", (Bandung: Remaja Rosdakarya, 2011).

Moh. Hasim, "Implementasi Pendidikan Berbasis Masyarakat (Case Study Pelaksanaan Proses Pembelajaran di SLTP Alternatif Qoryah Thoyyibah Salatiga)", (Tesis: Universitas Negeri Semarang, 2007)

Muslich, Masnur, "Pendidikan Karakter, Menjawab Tantangan Krisis Multidimensional", (Jakarta: Bumi Aksara, 2011).

Samani, Muchlas, "Konsep dan Model Pendidikan Karakter", (Bandung: Remaja Rosdakarya, 2011).

Saptono, "Dimensi-dimensi Pendidikan Karakter, Wawasan, Strategi, dan Langkah Praktis", (Jakarta: Erlangga, 2011).

Schaeffer, Esther F, "It's Time For School to Implement Character Education", (NASSP Bulletin, Oktober, 1999, 83;1).

Sihombing, Umberto, "Konsep dan Pengembangan Pendidikan Berbasis Masyarakat", (Yogyakarta: Adicita Karya Nusa, 2001).

Sukmadinata, Nana Syaodih. "Pengembangan Kurikulum, Teori dan Praktek", (Bandung: PT Remaja Rosdakarya, 2001).

Sumpeno, Wahyudin. "Sekolah Masyarakat; Penerapan Rapid-Training-Design Dalam Pelatihan Berbasis Masyarakat", (Yogyakarta: Pustaka Pelajar, 2009). 
Suprayogo, Imam dan Tabrani, "Metodologi Penelitian dalam Penelitian Sosial Agama". (Remaja Rosdakarya, 2001).

Tilaar, H.AR, "Paradigma Baru Pendidikan Nasional", (Jakarta:Rineka Cipta, 2000). UU Sisdiknas No.23 Tahun 2003, Pasal 54 ayat 1 dan 2

Wiyani, Novan Ardy, "Membumikan Pendidikan Karakter di SD, Konsep, Praktik, dan Strategi", (Yogyakarta: Ar-Ruzz Media, 2013).

Zubaedi, "Pendidikan Berbasis Masyarakat", (Yogyakarta: Pustaka Pelajar, 2006). 